University of Nebraska - Lincoln

DigitalCommons@University of Nebraska - Lincoln

1997

\title{
Hands-On Geology for Navajo Nation Teachers
}

Russell Frank Dubiel

US Geological Survey

Stephen Tom Hasiotis

University of Colorado

Steven Christian Semken

Navajo Community College

Follow this and additional works at: https://digitalcommons.unl.edu/usgsstaffpub

Part of the Earth Sciences Commons

Dubiel, Russell Frank; Hasiotis, Stephen Tom; and Semken, Steven Christian, "Hands-On Geology for Navajo Nation Teachers" (1997). USGS Staff -- Published Research. 217.

https://digitalcommons.unl.edu/usgsstaffpub/217

This Article is brought to you for free and open access by the US Geological Survey at DigitalCommons@University of Nebraska - Lincoln. It has been accepted for inclusion in USGS Staff -- Published Research by an authorized administrator of DigitalCommons@University of Nebraska - Lincoln. 


\section{Hands-On Geology for Navajo Nation Teachers}

Russell Frank Dubiel

U.S. Geological Survey

MS 939 Denver Federal Center

Box 25046

Denver, Colorado 80225

e-mail: rdubiel@usgs.gov
Stephen Tom Hasiotis

Department of Geological Sciences

University of Colorado

Boulder, Colorado 80309-0250

e-mail: hasiotis@ucsu.colorado.edu
Steven Christian Semken

Navajo Dryland Environments Lab.

Navajo Community College

Shiprock, Navajo Nation,

New Mexico 87420-0580

e-mail: scsemken@ncc.cc.nm.us

\section{ABSTRACT}

The Navajo Nation comprises the largest land area and the largest population of any Native American community in the United States, and it hosts some of Earth's most spectacular geology. Geologic resources and environmental concerns have figured prominently in the Navajo Nation's recent history and economy. Despite the traditional cultural ties of the Diné (Navajo) people to their land, and the natural curiosity of most K-12 students about the earth, geoscience courses are virtually absent from curricula in Navajo Nation public schools. Many native-born teachers are familiar with the landscape and its cultural geography, but few have received formal training in geology and are not comfortable introducing it into their classrooms. A collaborative project between the U.S. Geological Survey and Navajo Community College has addressed this issue on a local scale by developing a classroom and field- intensive one-week summer course for Navajo Nation teachers with no previous geologic experience. The course introduced basic geologic principles, regional geology, and environmental issues and guided teacher participants in the preparation and assembly of their own comprehensive geologic teaching kits, which included local and exotic rock and mineral specimens, fossils and fossil replicas, maps, and geologic and environmental-science field gear.

Keywords: Earth science - teacher education; education - geoscience; education - precollege; education - special clientele; geology - field trips and field study; geology - women and minorities.

\section{INTRODUCTION}

Geology is critically important to the Diné (pronounced din-NEH), or Navajo, Nation. It has the largest land area of any Native American community in the United States, covering more than 25,000 square miles in the Four Corners region of New Mexico, Arizona, C'olorado, and Utah, an area about the size of West Virginia. The Navajo Nation also has the largest population of any Native American community. In addition, the Navajo Nation is host to some of the most spectacular and recognizable geologic features on Earth. The traditional culture of the Diné people is tied to their land and environment (for example, see Arthur and others, 1982; Kelley and Francis, 1994); the Navajo Nation's recent economy has largely been driven by geologic resources such as coal; and the Navajo Nation environment has been seriously impacted by extractive industries and by population growth.
Despite both their traditional ties to the land and the recent impact of geology on the society, Earth science is virtually absent from K-12 schools on and near the Navajo Nation. Most native-born teachers are familiar with the landscape and its cultural geography through names and legends that are derived from historical events or geomorphological characteristics (Begay, 1995). However, few teachers have received any significant formal training in science or science education, and even fewer teachers have studied undergraduate geology. Therefore, despite the natural curiosity most elementary-school students have about the earth, amplified by the Diné experience of living close to the land, most local teachers have not been comfortable teaching Earth science. This educational dilemma is exacerbated by the population distribution. The median age within the Navajo Nation is nineteen; thus virtually half of the people are $\mathrm{K}-12$ students.

The educational dilemma is now being addressed for pre-service teachers by means of expanding programs in Navajo teacher education and certification at Navajo Community College (NCC), the designated and accredited institution of higher education of the Diné people. A semester of introductory college geology is now required of all NCC elementary-education majors, and geoscience is a significant component of a new upper-division course in science-education methods designed by NCC under the auspices of the Arizona Collaborative for Excellence in Teacher Preparation, funded by the National Science Foundation.

\section{ADDRESSING THE NEEDS OF IN-SERVICE TEACHERS}

In contrast to advances made for pre-service teachers, a different approach is required for in-service teachers. In-service teachers cannot attend regular daytime classes; they usually have little free time until summer, and they are most attracted to programs that allow them to earn graduate-level (continuingeducation) credit for their efforts.

This collaborative project was designed to address all of these needs. We developed a week-long (fortyhour) summer course offering either two hours of graduate-level credit through the extension program of Adams State College (Alamosa, Colorado) or two hours of undergraduate credit through NCC (for preB.A. participants). Our objective was twofold: (1) to illustrate basic geological principles by means of classroom lectures and field exercises within the Navajo Nation and in close proximity to our participants' own schools, and (2) to provide the teachers with practical knowledge and teaching materials to bring back to their own students. Whenever possible, 


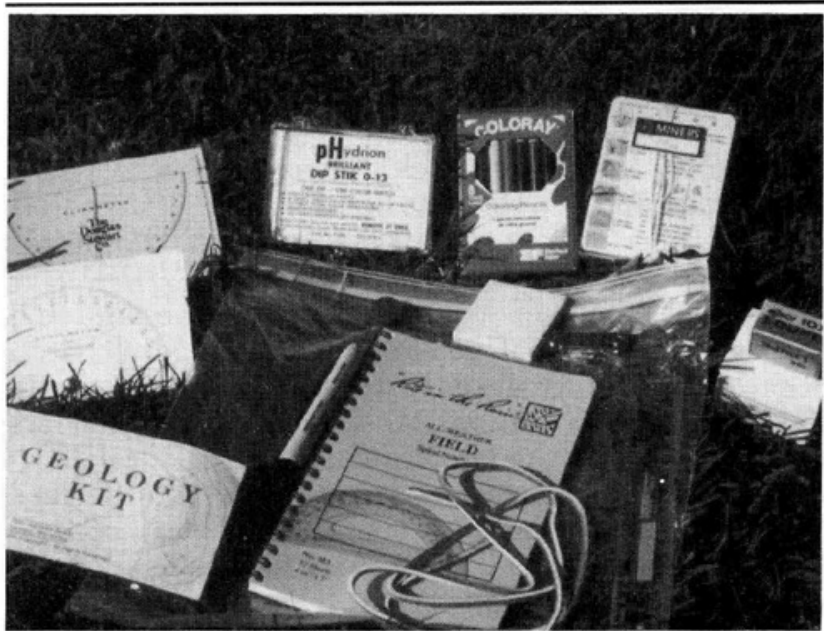

Figure 1. Some of the tools and materials provided to each teacher participant for use in the geologic teaching kits.

we intended for the teaching materials to be gathered by the participants themselves in order to reinforce the "Earth-science field experience" in each teacher. The encouragement of active participation would act as positive reinforcement to the teacher participants by providing opportunities to be successful in field trip planning and kit-making activities in their own classrooms.

The Hands-On Geology course design, preparation, and material acquisition were supported by a Human Resources Initiative Grant to the authors through the Geologic Division of the U.S. Geological Survey (USGS). Navajo Community College provided classroom and laboratory facilities, audio-visual support for the lectures and labs, and the van for fieldtrip transportation.

\section{IMPORTANT NOTE}

Field trips associated with this course, and all geologic studies within the Navajo Nation, are carried out with the cooperation of, and under written permit from, the Navajo Nation Minerals Department, located in Window Rock, Arizona (520-871-6587).

\section{THE COURSE}

Hands-On Geology for Navajo Nation Teachers met for one week in early June, 1995 at the NCC campus at Shiprock in northwest New Mexico, which is the largest community on the Navajo Nation (12,000 residents). Fourteen teachers took part; all were Navajo. More than half were pre-service teachers in the NCC elementary-education program. Enrollment was limited to fourteen simply because that was the capacity of our one van for field exercises. At least half again as many teachers were interested but could not be accommodated in this session of the course. A primary goal of the course was for the teachers to assemble their own geology teaching kits, which they would take back to their classrooms as a resource for their students.

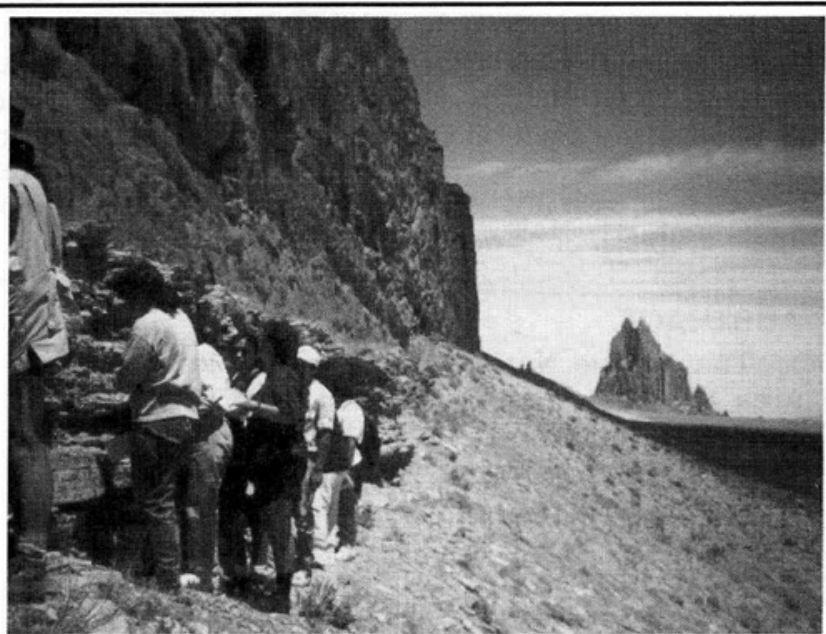

Figure 2. The Hands-On Geology class examines the contact between the Upper Cretaceous Mancos Shale and an Oligocene minette dike extending from the Ship Rock diatreme (visible in the distance).

\section{Classroom and Laboratory Activities}

Prior to the course presentation, the participants were given materials for lectures, laboratory presentations, and the teaching kits. These materials included lecture notes, photographic slides, maps and handouts on geologic principles and topics, plastic containers to house the assembled teaching kits, and basic geologic field gear (Figure 1), including hammers, hand lenses, acid bottles, notebooks, streak plates, $\mathrm{pH}$ test papers, and sample bags.

Classroom lectures were organized on a holistic theme of Earth systems that is concordant with traditional Navajo concepts of natural processes (Semken and Morgan, this issue). Specific topics included solid and fluid Earth cycles, Earth materials, geologic time, fossils, and the historical and environmental geology of the Colorado Plateau and the Navajo Nation. Each instructor also offered examples of how the science of geology works, based on his own professional experiences in the field and lab.

Laboratory exercises were designed to demonstrate the use of the newly acquired geological tools and to teach basic principles of interpretation and classification of Earth materials by means of the most easily observed macroscopic properties. Teacher participants learned to identify the rock-forming minerals most common to local formations and to distinguish the three basic "clans" of rocks. (Use of this term, which implies petrogenetic systems that encompass a host of diverse samples, offers instant comprehension to Diné, whose lives are governed by clan relationships.) They also learned to identify the major types of fossils found in local sedimentary strata. The participants offered their ideas as to how much detail in classifying Earth materials would be appropriate for their students.

\section{Field Exercises and Their Objectives}

Field exercises were designed to demonstrate the practical application of classroom knowledge and to 
collect specimens for the participants' teaching kits. Each field exercise had specific objectives. Our first trip, on the afternoon of the second day, demonstrated to our participants that good examples of all three "clans" of rocks - igneous, metamorphic, and sedimentary - can be found in the immediate vicinity of the community of Shiprock. The Navajo Nation region of the Colorado Plateau is best known for its thick sequence of colorful and fossiliferous Pennsylvanian to Tertiary sedimentary rocks, of which the group took maximum advantage all week, especially Cretaceous marine systems (Elder and Kirkland, 1995). In contrast, the nearby exhumed Oligocene diatreme Tsé bit'a'í (pronounced TSEH-bit-ah, meaning "rock with wings"), or Ship Rock, and its associated dikes (Figure 2) yielded examples of hypabyssal minettes, breccias, and granitic xenoliths. Terrace gravels deposited by the San Juan River provided specimens of a host of metamorphic and igneous rocks derived from the distant San Juan and $\mathrm{La}$ Plata Mountains.

On the second field trip, the group spent a day in the Monument Valley area, along the northern border of the Navajo Nation, examining the Permian, Triassic, and Jurassic stratigraphy and structure exposed in a classic anticline. Discussions and field examinations covered the Permian rock types and sedimentary structures, Triassic rocks and uranium mineralization, sandstone and shale rock types, and discussions of erosion and landform evolution.

The third field excursion visited Red Valley, on the periphery of the San Juan Basin southwest of Shiprock, to examine Jurassic and Cretaceous rocks. Coal, petroleum, and natural gas are mined extensively nearby, and this trip provided an appropriate setting for a discussion of the environmental geology of fossil fuels and their impact on and importance to society.

\section{TEACHING KITS:}

\section{TEACHER-DESIGNED, TEACHER-FRIENDLY}

An important aspect of the Hands-On Geology course was to guide participants in the selection, identification, and classification of their own mineral, rock, and fossil specimens to be included with the geologic and environmental tools in their teaching kits. Specimens were collected with the maps and field gear provided. The classroom kits, because they were organized by the teachers themselves for their own individual classrooms and age groups, would be inherently "teacher-friendly" and, thus, more likely to be used extensively after the course ended. Our basic template was derived from a series of rock and fossil kits made available to K-12 teachers in the Denver area by the GeoScience Center of the USGS. The original kits were designed by Bob O'Donnell, now retired from the Survey. What distinguished the Hands-On Geology kits in our course from their predecessors is that we provided only an empty carrying case and plastic sample bags, basic geology field equipment (for example, rock hammer, hand lens, acid bottle, notebooks; see Figure 1) that teachers would need to collect samples, and a few large samples of

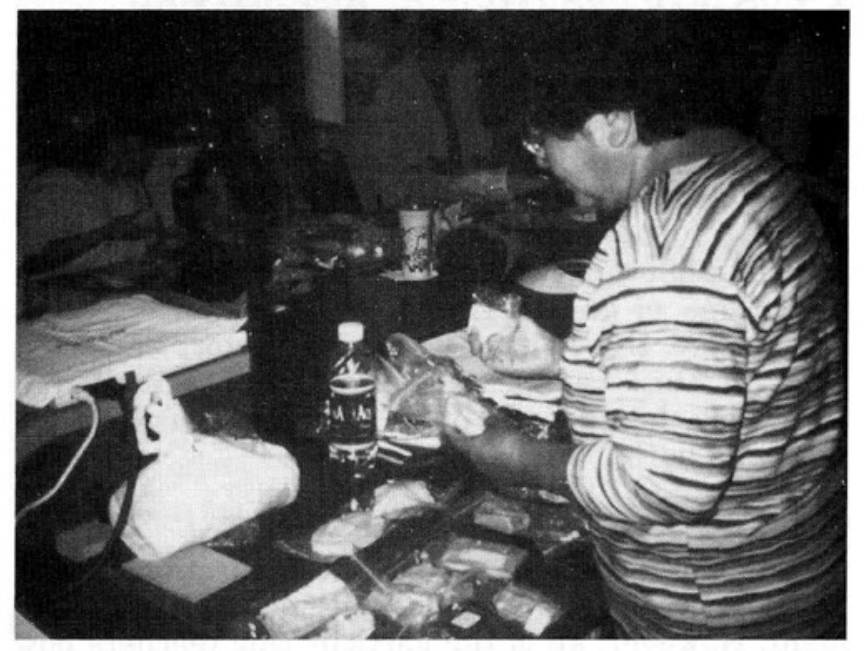

Figure 3. In teams of two, teacher participants devise their own schemes for the classification of geological specimens.

rock-forming minerals, rocks, and fossils or casts of fossils (for example, trilobites, crinoids, dinosaur footprints, dinosaur claw, fossil horse teeth) that could not be obtained nearby. Considerable space remained in each kit for the specimens that the teachers themselves would collect and identify.

A successful exercise with the kits involved grouping all the specimens - minerals, rocks, and fossils - by common diagnostic characteristics (those that the teachers would expect their students to recognize). Teachers worked in seven teams of two and spent about 30 minutes grouping their specimens according to criteria they themselves defined (Figure 3). After the time limit, each team presented one of its specimen groups to the entire class and defended their reasons for the selection. As each team of teachers introduced a new group, the teams that followed were increasingly hard pressed to identify characteristics that had not already been named. However, every team was able to introduce at least two distinct kinds of groups. Ultimately, fifteen different groupings were presented and recorded on a whiteboard. The teachers were then asked to collectively review their initial list of groups and condense it into a simpler, workable system defined by characteristics shared across groups. For example, trilobites could be grouped with crabs as arthropods and then with other invertebrate fossils. The dinosaur footprints could be grouped with the dinosaur tooth and claw, and with fossil horse teeth, because they are all vertebrate fossils. In this way, with minimal direction from the professional geologists, the teachers developed a classification system for their teaching kits that was pedagogically robust and practical for their use.

This exercise demonstrated to the teachers that understanding the principles of classification used in geology and paleontology would also promote the development of basic skills in observation, conceptualization, and organization by means of an exercise that would be interesting and fun for students. 


\section{A TWO-WAY EXCHANGE OF INFORMATION}

The instructors shared their collective knowledge of geology, paleontology, and environmental science. Equally importantly, the participants taught the instructors a great deal about Navajo culture: useful or otherwise interesting linguistic expressions; customs relating to outdoor activities and socializing; and natural philosophy, including traditional Diné interpretations of the origin of local landforms. Most memorably, the visiting USGS instructors enjoyed a week of Diné cuisine, including roast mutton and corn stew, home-made breads and tortillas, and indigenous herbal tea.

\section{FOLLOW-UP AND FUTURE PLANS}

The minimal budget and short duration of this pilot project did not allow for a formal plan of assessment. However, all of the participating teachers now working in the Shiprock area have remained in contact with the NCC instructor, who has also visited several classrooms to observe the kits in use. At the end of the summer course, all of the participants were encouraged to make use of the NCC geology program as a continuing source of additional information and materials, and some have done so.

We are currently developing a manual that outlines the development and staging of the course, which also includes an itemized description of the teaching kits assembled by our participants. HandsOn Geology for Navajo Nation Teachers has been added to the NCC course listing as Geology 198, and participants in the next class (scheduled for summer 1997 pending funding) will earn credit specifically transferable to a new BA program in elementary education now offered at NCC or an MA/MS program in science education at one of several New Mexico universities.

\section{ACKNOWLEDGMENTS}

Financial support for this project was provided by a 1995 Human Resources Initiative Grant from the Geologic Division, USGS, and by the Waste-Management Education and Research Consortium through NCC. We are extremely grateful to Laure Wallace for her encouragement and support through the Human Resources Program of the USGS. We thank the Navajo Nation Minerals Department for permission to conduct field activities on the Navajo Nation and Adams State College for authorizing graduate credit for our course.

We aiso thank Tom Michalski and the Core Research Center of the USGS for providing many of the rock and mineral specimens for the teaching kits; Eric Fisher and Elly Brouwers of the USGS for providing many of the fossil specimen casts; and Carol Hasiotis for organizing and assembling the packages of specimens for the students. RFD and STH thank the USGS for providing the time and opportunity to carry out this project successfully. All three of us say Ahéhee' - thank you - to our first group of Navajo Hands-On Geology teachers for their enthusiasm and for all they shared with us.

\section{REFERENCES CITED}

Arthur, Claudeen, and others, 1982, Between sacred mountains: Chinle, Arizona, Rock Point Community School, p. 1-5.

Begay, Lydia Fasthorse, 1995, Diné bikéyah dóó bizaad yee nildzil: Inter-Tribal America, p. 48-54.

Elder, William P., and Kirkland, James I., 1995, Cretaceous paleogeography of the southern Western Interior, in Caputo, Mario V., Peterson, James A., and Franczyk, Karen J., editors, Mesozoic systems of the Rocky Mountain region: Denver, Rocky Mountain Section, Society of Economic Paleontologists and Mineralogists, p. 415440.

Kelley, Klara Bonsack, and Harris, Francis, 1994, Navajo sacred places: Bloomington, Indiana, Indiana University Press, $260 \mathrm{p}$.

Semken, Steven C., and Morgan, Frank, 1997, Navajo pedagogy and Earth systems: Journal of Geoscience Education, v. 25, p 106.

\section{ABOUT THE AUTHORS}

Russell Dubiel ( $\mathrm{PhD}$, University of Colorado) is a research geologist with the Energy Resources Team of the U.S. Geological Survey. His research is on Permian, Triassic, Jurassic and Cretaceous depositional systems, paleoclimates, and fossil fuels and energy resources. $\mathrm{He}$ is actively involved in geologic outreach, teaching courses and lecturing at community colleges, universities, and public schools.

Steve Hasiotis (PhD, University of Colorado) recently completed his dissertation on the evolution of animal behavior and ecosystems in the Mesozoic and Cenozoic rocks in the Rocky Mountain region. He is also active in community outreach, teaching others about the importance of understanding local and regional geology, paleontology, and ancient and modern ecology.

Steve Semken (PhD, Massachusetts Institute of Technology) is an environmental geologist who constitutes the entire geology department at NCC Shiprock Campus. He is a devoted student of the geological, environmental, and ethnological attributes of the central Colorado Plateau, assisted in great measure by his Navajo wife and in-laws.

\section{Food for Thought}

... responsible individualism should be considered a component of intelligence. It is the most adaptive practical response to the world in which we live.

William A. Henry III, 1994, In defense of elitism:

New York, Doubleday, 212 p. (from p. 143). 